\title{
What do you know about conservation and human rights?
}

\author{
Helen Newing and Anouska Perram
}

Under what circumstances do you think it is morally acceptable to stop local communities from hunting for food inside a protected area? Or from gathering honey and wild herbs? Or practising traditional shifting agriculture? Is it acceptable to create a protected area on community lands without consultation or consent? What about forced displacement of local communities? Shoot-to-kill policies? All of these actions are reported to have been carried out in the name of conservation in recent years (e.g. Tauli-Corpuz, 2016, 18-22; Mogomotzi \& Kefilwe, 2017). But how much is this simply a matter of moral discretion and how much is it governed by international human rights obligations?

To address these questions we must first understand what international law has to say on human rights. Firstly, it says there are universal rights held by all human beings that are inalienable (they cannot be given or taken away), unconditional (they do not depend on behaviour), indivisible and interdependent (they are all equally important and they cannot be separated) and non-discriminatory. The Universal Declaration of Human Rights includes the much-cited right to life, liberty and security of person (Article 3); the right of freedom from torture and 'arbitrary arrest, detention or exile' (Articles 4 \& 9); the right not to be subjected to 'arbitrary interference with his [sic] privacy, family, or home' (Article 12) or to be 'arbitrarily deprived' of property (Article 17.2). These are important considerations in relation to conservation, not only with respect to shoot-to-kill and involuntary resettlement, but also for restrictions on people's ownership of, access to and use of land and natural resources.

Secondly, it says that in addition to individual rights there are also collective rights. Binding international instruments that protect collective rights include the International Covenant on Civil and Political Rights, the International Covenant on Economic, Social and Cultural Rights, the International Convention against All Forms of Racial Discrimination, the American Convention on Human Rights, the African Charter on Human and Peoples' Rights, and the International Labour Organization's Convention 169 on the rights of Indigenous and tribal peoples. These rights include the right of self-determination (which is the right of all peoples to determine their own future), the right to

Helen Newing Interdisciplinary Centre for Conservation Science, University of Oxford, Oxford, UK. E-mail h.s.newing@gmail.com

Anouska Perram Forest Peoples Programme, Moreton-in-Marsh, UK own, possess, manage and use their ancestral lands and natural resources; the right to enjoy, practise and maintain their culture; the right to participate in the management and conservation of resources on their lands; and, more broadly, the right to participate effectively in decision-making in all matters that would affect their rights. The United Nations Declaration on the Rights of Indigenous Peoples further clarifies these rights and, although it is a non-binding instrument, it is widely regarded as a restatement of existing binding principles. Obviously these rights and international obligations are of direct relevance to conservation, including in relation to protected areas governance.

Thirdly, rights are just that-rights-and as such international law requires that they should be respected, protected and fulfilled by governments, who are the 'primary dutybearers'. 'Respect' means abstaining from doing anything that violates rights, 'protect' means preventing violation of rights by others and guaranteeing access to remedy where violations do occur, and 'fulfil' means taking necessary measures to enable people to claim or enjoy their rights. Other institutions, including conservation organizations, are secondary duty-bearers and also have a responsibility to respect rights ('do no harm'), which means avoiding activities that cause violations, and avoiding contributing to human rights violations by others. The United Nations Guiding Principles on Business and Human Rights (UN, 2011) sets out the responsibilities of businesses in this respect.

In fact all actors have an obligation to strenuously seek to avoid any encroachment upon rights. One aspect of this is that fulfilment of human rights may be restricted where to do so is necessary and proportionate to a legitimate objective in a democratic society. An action that has the effect of denying an Indigenous people 'their survival as a tribal people' will not meet these requirements (e.g. IACHR, 2007, paragraph 128). For restrictions to be compatible with international legal obligations it must be demonstrated that (1) the objective is legitimate, (2) the peoples concerned are a substantial cause of the problem, (3) no less restrictive measures would adequately achieve the objective, and (4) the impacts that would be caused are proportionate to the predicted benefits (Mackay, 2017).

Also of relevance is the concept of free, prior and informed consent, which is concerned principally with requirements for consultation in relation to measures that may affect Indigenous and traditional peoples. The purpose of consultation is to seek mutually acceptable solutions that adequately satisfy a proposal's legitimate objective, but also limit, remove 
and/or compensate for encroachment on Indigenous peoples' substantive rights, such as the right to lands and natural resources. In some circumstances-including cases involving relocation or for large-scale projects with significant impacts on use and enjoyment of territories-a proposal may not proceed without the affected peoples' consent (e.g. IACHR, 2007, paragraphs 134-137).

What, then, does this mean for conservation? It means that before considering the creation of a protected area and restrictions on local peoples' access and resource use, there needs to be a full and participatory analysis of the conservation problem: its severity; what the drivers are and what role local people play (if any); what exactly needs to change to address any part of the problem related to local people and what the alternative paths are to accomplish this; and whether the social impacts would be proportionate. Mitigation hierarchies, which are used widely in conservation (e.g. Bull et al., 2018), could easily be adapted to incorporate rights obligations along these lines.

Here's one more question: do you know what formal commitments the major conservation organizations have already made in relation to human rights? They are very impressive, at least as written, and date back over at least 4 decades. IUCN first recognized the right of traditional societies to self-determination nearly 40 years ago at the 1982 World Parks Congress, and has continued to pass resolutions to this effect at its Congresses ever since (Macinnes et al, 2017). Several of the major nongovernmental conservation organizations have made equally strong commitments, and in 2009 Conservation International, Fauna \& Flora International, IUCN, The Nature Conservancy, Wetlands International and WWF signed the Conservation and Human Rights Framework (IUCN, 2009), which reaffirms commitments to respect internationally proclaimed human rights, including those in the United Nations Declaration on the Rights of Indigenous Peoples and in International Labour Organization Convention 169. Yet these commitments are rarely invoked in current debates about conservation and many conservationists are completely unaware of them.

So how have these obligations played out in relation to conservation? How enforceable are they? Some recent Court rulings provide some illustrations (MacKay, 2017):

Endorois Welfare Council (2010) The African Commission on Human and Peoples' Rights ruled that the denial of the Endorois' property rights over their ancestral land was 'disproportionate to any public need served by the Game Reserve' and ordered that lands be returned to the Endorois.

Ogiek case (2017) The African Court on Human and Peoples' Rights ruled that Kenya had 'not provided any evidence' to support its claim that occupation by the Ogiek was detrimental to the environment. The test of necessity was therefore not satisfied and the Court ordered the return of lands to the Ogiek.

Kaliña and Lokono (2015) The Inter-American Court of Human Rights ordered Suriname to delimit the lands of the Kaliña and Lokono Peoples, as part of which it was required to consider restitution of lands classified as a nature reserve. It also ruled that the absence of explicit mechanisms guaranteeing their access, use and effective participation in the nature reserve was a violation of human rights.

These cases emphasize that conservationists urgently need to reopen discussions about rights. It is sometimes argued that talking about rights closes down discussion, but when reports of serious abuses are so widespread it seems that not talking about rights is far more certain to close down discussion.

In conclusion, we believe that it is time for conservationists and conservation institutions to get to grips with international law on rights and to ensure that conservation actions are not only effective, but also compatible with international law and morally responsible. We need not only to build on common interests between conservationists and local communities wherever these occur, but also to engage in honest discussion about genuine conflicts of interest where these exist and work towards negotiated settlements, with full respect for rights as the bottom line. International law provides rules as to how to approach this. Finally, we need to take action to strengthen institutional memory and accountability if we are to restore trust in the conservation movement, both with Indigenous and local communities and also with the international human rights community and the broader public.

\section{References}

Bull, J., Baker, J., Griffiths, V.F., Jones, J. \& Milner-Gulland, E.J. (2018) Ensuring No Net Loss for people as well as biodiversity: good practice principles. SocArXiv. Osf.io/preprints/socarxiv/4ygh7. IUCN (2009) Conservation and Human Rights Framework: Conservation Initiative on Human Rights. Http://cmsdata.iucn.org/ downloads/cihr_framework_e_sept2010_1.pdf [accessed 18 July 2019].

IACHR (Inter-American Court of Human Rights) (2007) Case of the Saramaka People v. Suriname. Judgment of November 28, 2007. Http://www.corteidh.or.cr/docs/casos/articulos/seriec_172_ ing.pdf [accessed 18 July 2019].

MacKay, F. (2017) Indigenous Peoples' Rights and Conservation: Recent Developments in Human Rights Jurisprudence. Https://www. forestpeoples.org/en/rights-based-conservation/news-article/2017/ indigenous-peoples-rights-and-conservation-recent [accessed 18 July 2019].

Macinnes, A., Colchester, M. \& Whitmore, A. (2017) Free, prior and informed consent: how to rectify the devastating consequences of harmful mining for Indigenous peoples. Perspectives in Ecology and Conservation, 15, 152-160.

Mogomotsi, E.J. \& Kefilwe, P. (2017) Live by the gun, die by the gun: Botswana's 'shoot-to-kill' policy as an anti-poaching strategy. South Africa Crime Quarterly, 60, 51-59.

TAuli-Corpuz, V. (2016) Report of the Special Rapporteur of the Human Rights Council on the Rights of Indigenous Peoples. United Nations General Assembly A/71/229. Https://www.un.org/ development/desa/indigenouspeoples/wp-content/uploads/sites/ 19/2019/01/N1624109.pdf [accessed 18 July 2019].

UN (United Nations) (2011) Guiding Principles on Business and Human Rights. Https://www.ohchr.org/Documents/ Publications/GuidingPrinciplesBusinessHR_EN.pdf [accessed 18 July 2019]. 